\title{
A multiplex marker set for microsatellite typing and sexing of sooty terns Onychoprion fuscatus
}

Lucy J. H. Garrett ${ }^{1,2^{*}}$, Deborah A. Dawson², Gavin J. Horsburgh ${ }^{2}$ and S. James Reynolds ${ }^{1,3}$

\begin{abstract}
Objectives: Seabirds have suffered dramatic population declines in recent decades with one such species being the sooty tern Onychoprion fuscatus. An urgent call to re-assess their conservation status has been made given that some populations, such as the one on Ascension Island, South Atlantic, have declined by over $80 \%$ in three generations. Little is known about their population genetics, which would aid conservation management through understanding ecological processes and vulnerability to environmental change. We developed a multiplex microsatellite marker set for sooty terns including sex-typing markers to assist population genetics studies.

Results: Fifty microsatellite loci were isolated and tested in 23 individuals from Ascension Island. Thirty-one were polymorphic and displayed between 4 and 20 alleles. Three loci were Z-linked and two autosomal loci deviated from Hardy-Weinberg equilibrium. The remaining 26 autosomal loci together with three sex-typing makers were optimised in seven polymerase chain reaction plexes. These 26 highly polymorphic markers will be useful for understanding genetic structure of the Ascension Island population and the species as a whole. Combining these with recently developed microsatellite markers isolated from Indian Ocean birds will allow for assessment of global population structure and genetic diversity.
\end{abstract}

Keywords: Ascension island, Colonial seabird, Conservation, Microsatellite loci, PCR, Population genetics, Relatedness, Sex-typing

\section{Introduction}

Sooty terns Onychoprion fuscatus are long-lived pelagic seabirds distributed throughout the tropical oceans where their range covers in excess of $20,000 \mathrm{~km}^{2}$ [1]. They are obligate colonial breeders nesting in large numbers, with birds breeding on Ascension Island in the South Atlantic Ocean constituting 40\% of the Atlantic population. The long-term study of demographics and life history $[2,3]$, make it an ideal study population in which to investigate genetic structure and diversity. Genetic diversity is fundamental for populations to adapt to environmental change [4]. Declining and small populations often

\footnotetext{
*Correspondence: LJG478@bham.ac.uk

${ }^{1}$ Centre for Ornithology, School of Biosciences, College of Life \& Environmental Sciences, University of Birmingham, Edgbaston, Birmingham B15 2TT, UK

Full list of author information is available at the end of the article
}

suffer from inbreeding depression and reduced genetic diversity making them vulnerable to extinction [4].

The sooty tern population on Ascension Island declined by $84 \%$ between 1942 and 2005 [3]. A recent study of long-term population trends on Ascension Island prompted an urgent call for reclassification of their IUCN (International Union for Conservation of Nature) status from 'Least Concern' to 'Critically Endangered' [3]. This decline mirrors that of seabirds globally with pelagic seabirds being the most threatened [5]. A number of issues are thought to exert pressure on seabird populations including declining fish stocks, climate change, pollution and introduced predators at breeding grounds [6].

Since 2000 the breeding population on Ascension Island has occupied two main areas at Mars Bay and Waterside that are approx. $3 \mathrm{~km}$ apart (Fig. 1). Finescale DNA analyses would enable assessment of withinpopulation genetic structuring and highlight potential 


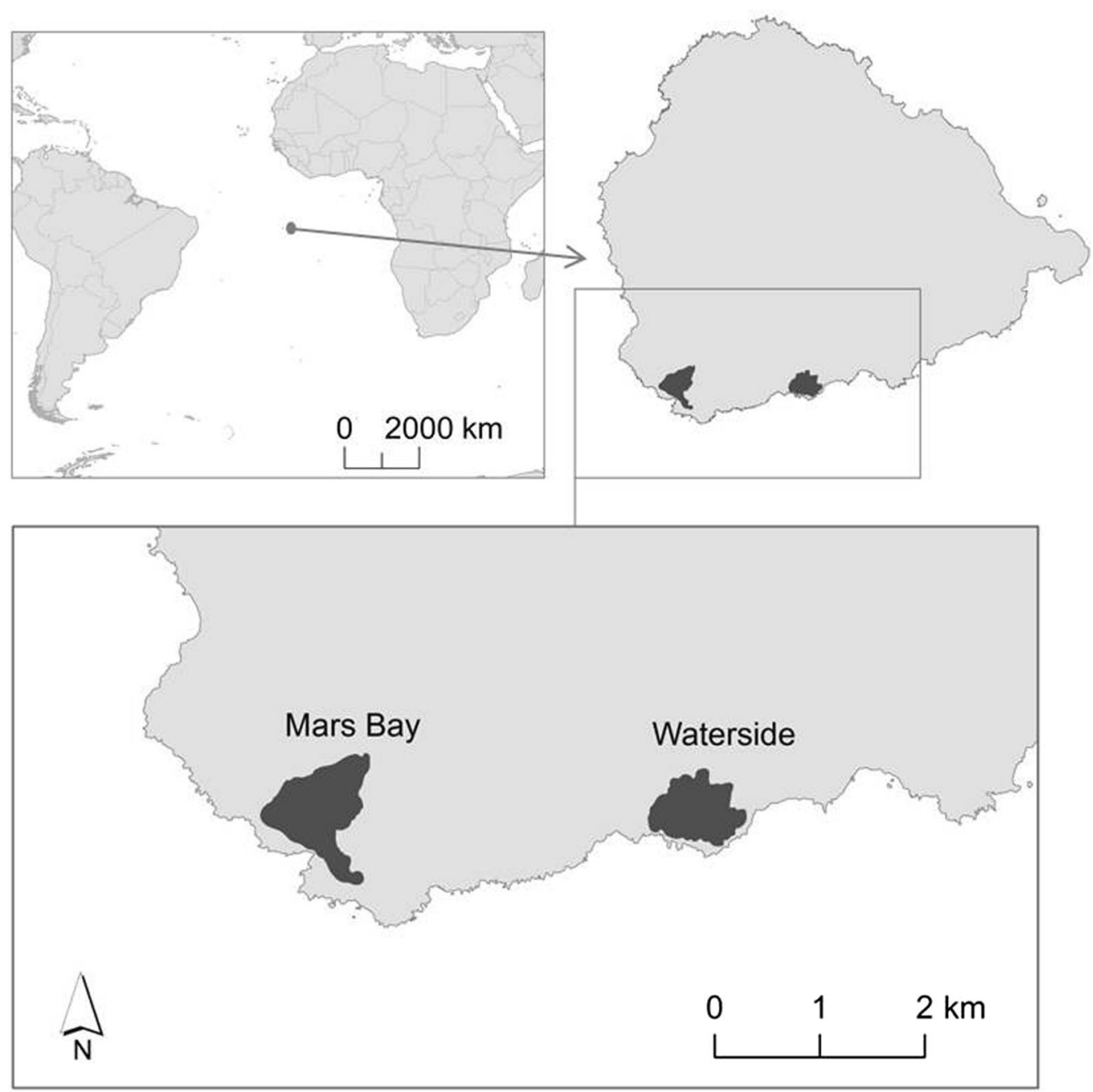

Fig. 1 Relative locations of Ascension Island in the South Atlantic and of the study colonies of sooty terns Onychoprion fuscatus on the island. Dark grey areas represent the cumulative extent of peak breeding occupancy by birds between 1996 and 2016 (inclusive). Ascension Island base map source: Ascension Island Government Conservation and Fisheries Department (AIGCFD)

barriers to gene flow. Microsatellite markers are an ideal tool with which to study demographic processes such as relatedness, inbreeding and genetic mixing mechanisms. Despite their widespread distribution, such processes have not been investigated in detail in this species. Sixteen microsatellite loci, were recently isolated from the Indian Ocean population [7], and given genetic differences have been documented between oceanic basins, combining these with markers derived from Atlantic Ocean birds would aid global-scale assessment of population structure. This would assist conservation management through understanding population ecology, evolutionary processes and vulnerability to environmental change.

\section{Main text}

\section{Methods and Results}

Genomic DNA was extracted from blood samples using an ammonium acetate precipitation method [8, 9]. Microsatellite sequences were isolated from a single adult sooty tern (BTO ring number DE97026) from a blood sample collected on Ascension Island in May 2014 at Mars Bay (Fig. 1). Sooty terns are sexually monomorphic [10], but genetic sex-typing of this individual using three sex-typing markers revealed it was a male (sex markers: Z002A, Z002D, [11] and Z43B, [12]). DNA concentration was quantified using a fluorimeter (FluostarOptima, BMG LABTECH Ltd., Aylesbury, UK) and its quality assessed by electrophoresis. The library was created by 
digesting the DNA with the restriction enzyme MboI and enriching the MboI fragments for the dinucleotide microsatellite motifs (CA)n, (GA)n, (TC)n,(TG)n using magnetic beads in the hybridisation [13, 14]. An Illumina paired-end library was created using $1 \mu \mathrm{g}$ of the repeat-enriched genomic DNA. The NEBNext Ultra DNA Library Prep Kit for Illumina (New England Biolabs Ltd. Hitchin, UK) protocol was followed and sequencing conducted using a MiSeq Benchtop Sequencer (Illumina Inc., San Diego, CA, USA). Sequencing was undertaken as two $\times 250$ bp paired-end reads generating 1,292,242 sequences. These were trimmed for quality and Illumina adapters removed using Trimmomatic [15] and paired reads aligned using FLASH [16]. SAULA/B-linker sequences [13] were removed and consensus sequences created with QDD [17]. Finally suitable microsatellites were identified using MISA [18]. A total of 423 unique sequences were selected for potential primer design, based on a minimum of five tandem repeats and a flank of $20 \mathrm{bp}$ on either side of the repeat region. These displayed five to 29 uninterrupted pure repeats (di, tri, tetra, pent and hex nucleotides) or possessed compound repeat regions (37 sequences). The lengths of the sequences obtained ranged from 196 to $457 \mathrm{bp}$ in length. From the 423 sequences, those with at least eight tandem repeats were selected for primer design; primer sets were designed using PRIMER3 v 0.4.0 [19, 20]. Specifications for primer selection were set at a length of 16 to 36 base pairs (optimum $20 \mathrm{bp}$ ), an optimal primer melting temperature of $59-61{ }^{\circ} \mathrm{C}$ (optimum $60{ }^{\circ} \mathrm{C}$ ), a maximum poly-X of three tandemly repeating nucleotides e.g. AAA, presence of a G/C clamp and the default settings for all other parameters. Fifty primer sets were designed. The $5^{\prime}$ end of the forward primers was fluorescently labelled initially with HEX or 6-FAM. Uniqueness of each set of sequence primers was verified using BLAST software [21].

Genotyping was carried out using DNA extracted from blood samples from 23 breeding birds from Mars Bay and Waterside (12 and 11 individuals, respectively) on Ascension Island (Fig. 1) during the December 2015 breeding period. Initially, each locus was amplified separately (singleplexed) in all individuals. All loci were PCR amplified using fluorescently labelled forward primers using either 6-FAM or HEX initially (Additional file 1: Table S1). QIAGEN's Multiplex PCR kit (QIAGEN, Manchester, UK) was used to perform PCRs following the manufacturer's protocol, but using a $2 \mu \mathrm{l}$ reaction volume added to $1 \mu \mathrm{l}$ of air-dried DNA (following [22]). The same PCR profile was used to amplify each locus as follows: $95{ }^{\circ} \mathrm{C}$ for $15 \mathrm{~min}$, followed by 44 cycles of $94{ }^{\circ} \mathrm{C}$ for $30 \mathrm{~s}, 56^{\circ} \mathrm{C}$ for $90 \mathrm{~s}, 72{ }^{\circ} \mathrm{C}$ for $90 \mathrm{~s}$ and a final step of $72{ }^{\circ} \mathrm{C}$ for $30 \mathrm{~min}$.
Three sex-typing markers (Z002A, Z002D [11] and Z43B [12]), were included to assign sex as little sexual dimorphism exists in sooty tern plumage [10, 23]. For genotyping, $1 \mu \mathrm{l}$ of PCR product was diluted to a ratio of 1:80 $\mathrm{H}_{2} \mathrm{O}$ and $1 \mu \mathrm{l}$ of this solution was added to $9 \mu \mathrm{l}$ formamide and $0.2 \mu \mathrm{l}$ of 500-ROX size standard (Applied Biosystems, Warrington, UK). An ABI 3730 DNA Analyser was used to separate PCR products and alleles were scored using GENEMAPPER v 3.7 (Applied Biosystems, Foster City, CA, USA). Of the 50 primer sets tested, 14 either did not amplify or produced a non-specific product, five loci were monomorphic and three were Z-linked (the 13 males were heterozygous or homozygous but all 10 females were homozygotes with sexes identified using genetic sex-typing markers; see Additional file 1: Table S1). Multiplexing was undertaken using the same QIAGEN Multiplex PCR Kit and profile as previously outlined (see Table 1).

To ensure allele frequencies were not biased by overrepresentation of genotypes through inclusion of related individuals [24], pairwise relatedness was estimated using ML-Relate [25], and confirmed individuals were unrelated with $\mathrm{r}<0.16$ (Mean $\pm \mathrm{SD}=0.01 \pm 0.03$ ). Observed and expected heterozygosities and predicted null allele frequencies were calculated in CERVUS v3.0.7 [26]. Departures from Hardy-Weinberg equilibrium and linkage disequilibrium were estimated using GENEPOP v 4.2 [27]. To correct for multiple tests a false discovery rate control [28] was applied to linkage disequilibrium $p$ values. The probability of identity, which estimates the likelihood that two unrelated individuals selected at random from the same population will have the same genotypes, was calculated using GENALEX v $6.5[29,30]$. Two autosomal loci (Ofu28 and Ofu42) deviated from HardyWeinberg equilibrium (Additional file 1: Table S1). They also showed high predicted null allele frequencies ( $>10 \%)$ and, as a consequence, were not included in the final multiplex. All three Z-linked loci (Ofu27, Ofu37 and Ofu43) were polymorphic (Additional file 1: Table S1) and did not deviate from Hardy-Weinberg equilibrium when assessed only in males. Although not included in the final multiplex, the three $z$-linked loci may be of utility for other studies. There was no evidence of significant linkage disequilibria between pairwise combinations of loci $(p>0.05)$. The 26 autosomal microsatellite loci, together with the three sex-typing markers, were combined into seven plexes by inclusion of the fluorescent dye NED (giving three dyes in total), to create a multiplex marker set using Multiplex Manager 1.2 [31] and validated (Table 1). The number of alleles per locus of the multiplexed autosomal loci ranged from four to 20 (Table 1), with an average of $10 \pm 5.6$ (SD) loci. Mean 


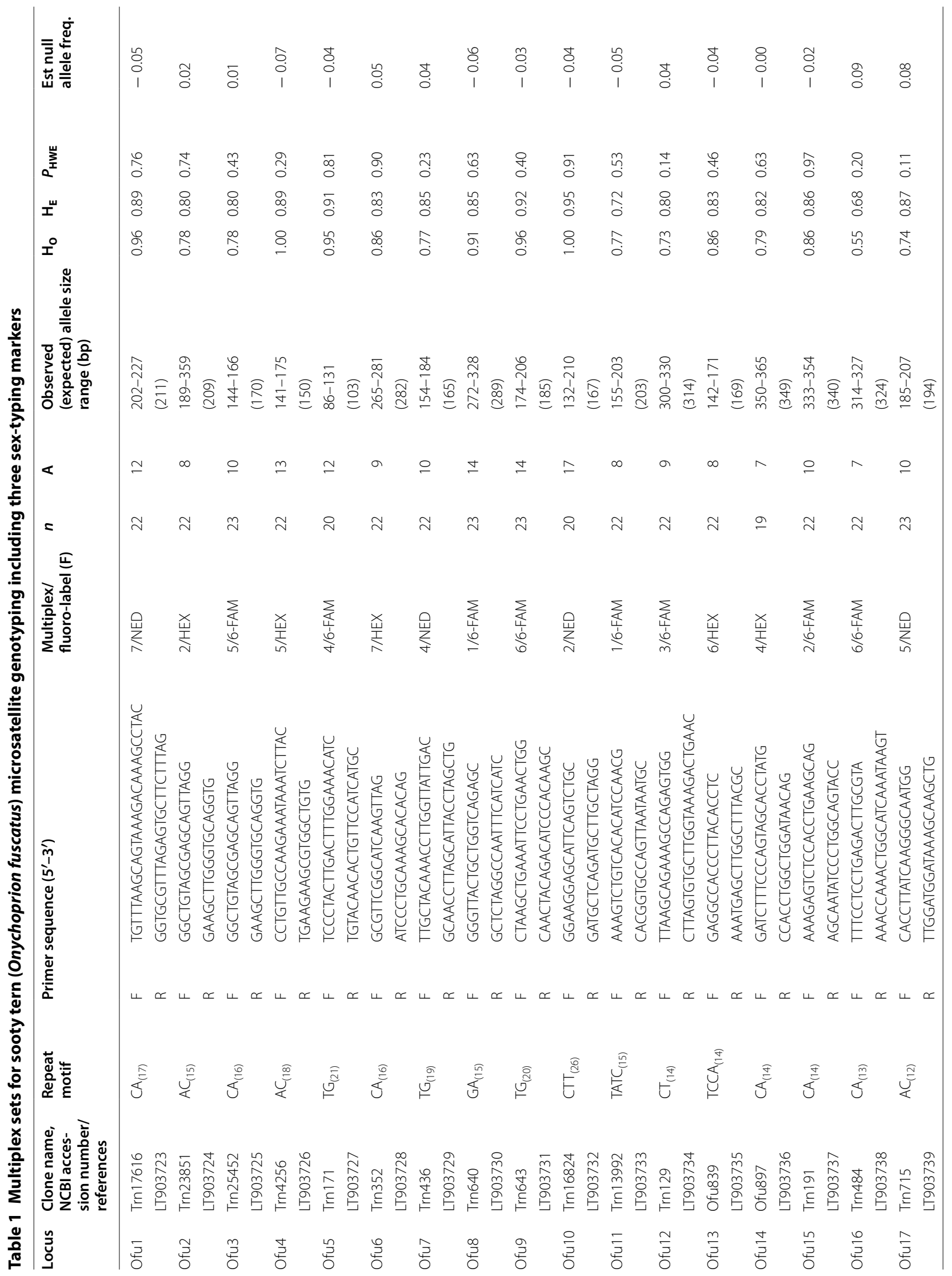




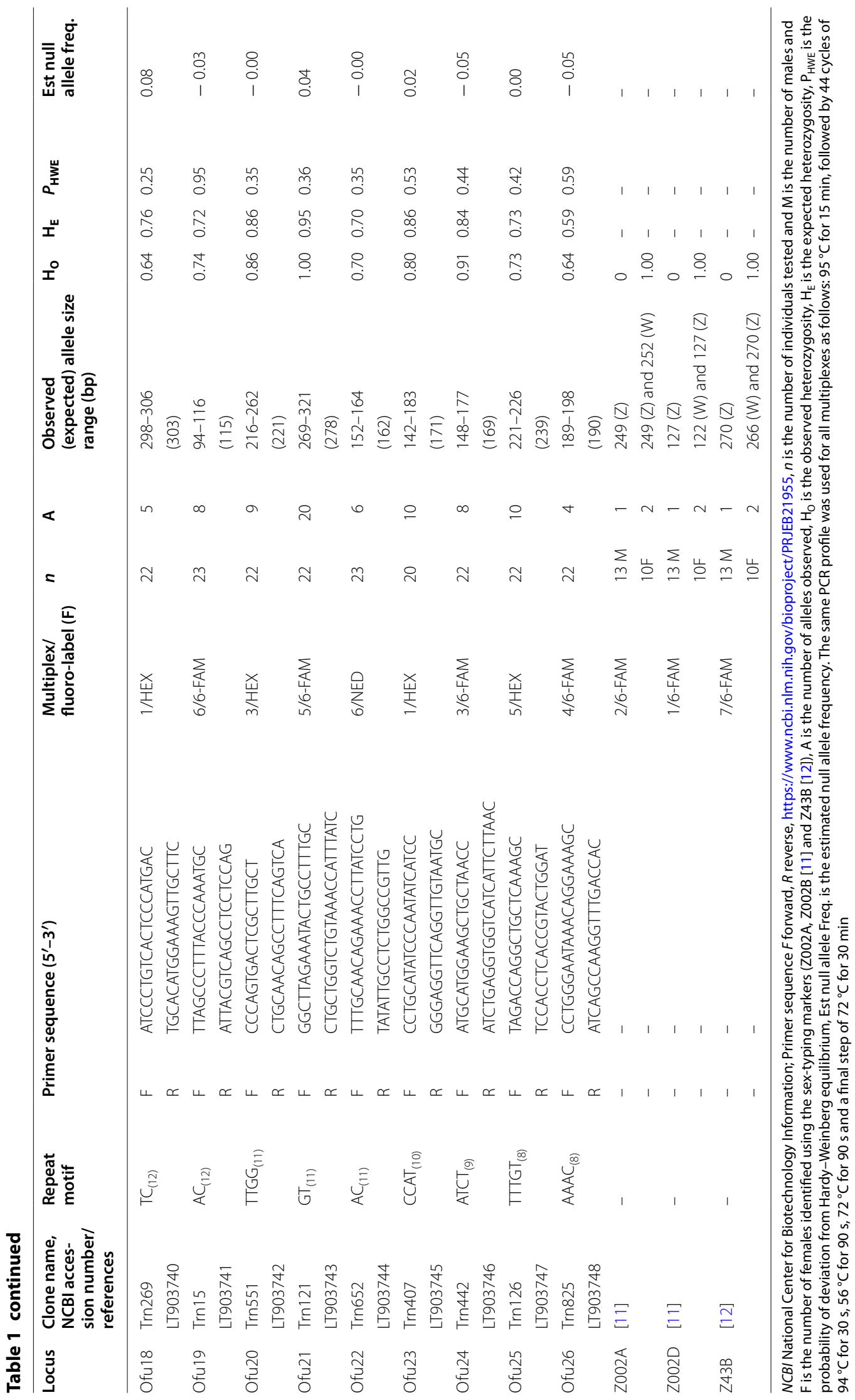


( $\pm \mathrm{SD})$ observed $\left(H_{\mathrm{O}}\right)$ and expected heterozygosities $\left(H_{\mathrm{E}}\right)$ were $0.82 \pm 0.12$ and $0.82 \pm 0.09$, respectively. The probability of identity for the 26 loci was $4.1 \times 10^{-33}$.

\section{Conclusions}

This multiplex set containing a large number of novel microsatellite loci together with the three sex-typing markers will be of great utility for fine- and large-scale population genetic structure analyses. More specifically, this multiplex set offers an effective and economical approach for investigating parentage assignment, relatedness and assisting conservation management plans for this colonial seabird. Combining this multiplex set with 16 microsatellite markers recently developed for sooty terns in the Indian Ocean [7] would allow for robust global population genetic analysis of this species, given differences in genetic variance have been documented between Atlantic and Indo-Pacific populations [32]. This is poignant given the recent urgent call for the reassessment of conservation status of this species [3]. An assessment of population and global scale genetic structure and diversity would highlight vulnerability to environmental change and persistent population declines. Where evidence for genetic mixing occurs, conservation management which focuses on larger populations in isolation may be detrimental to the long-term resilience of the species as a whole.

\section{Limitations}

The present study was carried out independently of the study by Danckwerts et al. [7] but ongoing discussions might result in collaborative testing of multiplex sets of primers on each research group's study populations from the Atlantic and Indian Oceans. We did not have DNA available from allied species of seabirds from Ascension Island and the utility of our multiplex set for species such as brown noddies (Anous stolidus) and black noddies (A. minutus) still needs to be assessed.

\section{Additional file}

Additional file 1: Table S1. Details of the 50 microsatellite markers tested in sooty terns (Onychoprion fuscatus). Markers Ofu1 to Ofu26 (inclusive) were included in the final multiplex set (see Table 1). Description of data: Results of the 50 microsatellite markers tested in sooty terns (Onychoprion fuscatus) from Ascension Island, including details of primer sequences, observed and expected allele sizes, and the analysis outcome for each primer.

\section{Abbreviations}

A. minutus: Anous minutus; AIG: Ascension Island Government; AOS: Army Ornithological Society; BTO: British Trust for Ornithology; DNA: deoxyribonucleic acid; $H_{\mathrm{E}}$ : expected heterozygosity; $H_{0}$ : observed heterozygosity; HWE: Hardy-Weinberg equilibrium; IUCN: International Union for Conservation of Nature; NCBI: National Center for Biotechnology Information; O. fuscatus:
Onychoprion fuscatus; PCR: polymerase chain reaction; SD: standard deviation; UK: United Kingdom.

\section{Authors' contributions}

LJHG and SJR conceived and designed the study. LHHG collected the samples. LJHG and GJH carried out laboratory work. LJHG and DAD analysed the data. LJHG, SJR and DAD wrote the paper. All authors read and approved the final manuscript.

\section{Author details}

${ }^{1}$ Centre for Ornithology, School of Biosciences, College of Life \& Environmental Sciences, University of Birmingham, Edgbaston, Birmingham B15 2TT, UK. ${ }^{2}$ Department of Animal and Plant Sciences, University of Sheffield, Sheffield S10 2TN, UK. ${ }^{3}$ Army Ornithological Society (AOS), c/o Prince Consort Library, Knollys Road, Aldershot, Hampshire GU11 1PS, UK.

\section{Acknowledgements}

Data collection was assisted by Katherine Mullin, the Ascension Island Government Conservation and Fisheries Department and the Army Ornithological Society, without whom this work would not have been possible. MiSeq sequencing was performed by Emilie Boardman of the Sheffield Diagnostics Genetics Service at The Children's Hospital Sheffield supported by the Sheffield Children's NHS Trust, UK. MiSeq sequences were processed by Helen Hipperson. Thank you to Julia Myatt, Jon Sadler and John Colbourne for their supervisory support and comments on the manuscript. Terry Burke provided helpful advice on genetics work. Special thanks also go to Teresa Santos and Natalie dos Remedios for motivational support during lab work and data analysis. This manuscript was much improved by the comments of two anonymous reviewers.

\section{Competing interests}

The authors declare that they have no competing interests.

\section{Availability of data and materials}

All data generated or analysed during this study are included in this published article and its additional files.

\section{Consent for publication}

Not applicable.

\section{Ethics approval and consent to participate}

All animal work was approved by the Local Ethics Review Committees of the University of Birmingham, the British Trust for Ornithology (BTO), and the Ascension Island Government (AIG). All ringing and marking of birds was carried out under BTO licence no. 6316 and blood sampling was carried out under Home Office licence.

\section{Funding}

This study was funded by a Natural Environment Research Council (NERC) CASE studentship to LJHG (NE/L002493/1) and by a NERC Biomolecular Analysis Facility (NBAF) grant to SJR (NBAF944) for laboratory work at the University of Sheffield, UK.

\section{Publisher's Note}

Springer Nature remains neutral with regard to jurisdictional claims in published maps and institutional affiliations.

Received: 20 October 2017 Accepted: 13 December 2017

Published online: 20 December 2017

\section{References}

1. Onychoprion fuscatus. (amended version published in 2016). 2017. http://www.iucnredlist.org/details/full/22694740/0. Accessed 07 June 2017.

2. Ashmole NP. The biology of the wideawake or sooty tern Sterna fuscata on Ascension Island. Ibis. 1963;103:297-351. 
3. Hughes BJ, Martin GR, Giles AD, Reynolds SJ. Long-term population trends of sooty terns Onychoprion fuscatus: implications for conservation status. Popul Ecol. 2017;59:213-24. https://doi.org/10.1007/ s10144-017-0588-z.

4. Frankham R. Genetics and extinction. Biol Conserv. 2005;126:131-40. https://doi.org/10.1016/j.biocon.2005.05.002.

5. Votier SC, Sherley RB. Seabirds. Curr Biol. 2017;27:R448-50. https://doi. org/10.1016/j.cub.2017.01.042.

6. Paleczny M, Hammill E, Karpouzi V, Pauly D. Population trend of the world's monitored seabirds, 1950-2010. PLoS ONE. 2015;10:e0129342. https://doi.org/10.1371/journal.pone.0129342.

7. Danckwerts DK, Lebarbenchon C, Le Corre M, Humeau L. Isolation and characterisation of 16 polymorphic microsatellite loci for the sooty tern (Onychoprion fuscatus; Sternidae), a super-abundant pan-tropical seabird, including a test of cross-species amplification using two noddies (Anous spp.). Mar Biodivers. 2017. https://doi.org/10.1007/s12526-017-0773-5.

8. Nicholls JA, Double MC, Rowell DM, Magrath RD. The evolution of cooperative and pair breeding in thornbills Acanthiza (Pardalotidae). J Avian Biol. 2000;31:165-76. https://doi.org/10.1034/j.1600-048X.2000.310208.X.

9. Richardson DS, Jury FL, Blaakmeer K, Komdeur J, Burke T. Parentage assignment and extra-group paternity in a cooperative breeder: the Seychelles warbler (Acrocephalus sechellensis). Mol Ecol. 2001;10:2263-73. https://doi.org/10.1046/j.0962-1083.2001.01355.x.

10. Schreiber EA, Feare CJ, Harrington BJ, Murray BG Jr, Robertson WR Jr, Robertson MJ, Woolfenden GE. Sooty tern (Sterna fuscata). In: Poole A, Gill F, editors. Birds of North America. 665th ed. Philadelphia: American Ornithologists' Union; 2002. p. 1-32.

11. Dawson DA. Genomic analysis of passerine birds using conserved microsatellite loci Ph. D. Thesis, University of Sheffield, UK; 2007.

12. Dawson DA, dos Remedios N, Horsburgh GJ. A new marker based on the avian spindlin gene that is able to sex most birds, including species problematic to sex with CHD markers. Zoo Biol. 2016;35:533-45. https:// doi.org/10.1002/zoo.21326.

13. Armour JA, Neumann R, Gobert S, Jeffreys AJ. Isolation of human simple repeat loci by hybridization selection. Hum Mol Genet. 1994;3:599-605.

14. Glenn TC, Schable NA. Isolating microsatellite DNA loci. Methods Enzymol. 2005;395:202-22. https://doi.org/10.1016/s0076-6879(05)95013-1.

15. Bolger AM, Lohse M, Usadel B. Trimmomatic: a flexible trimmer for Illumina sequence data. Bioinformatics. 2014;30:2114-20.

16. Magoc T, Salzberg SL. FLASH: fast length adjustment of short reads to improve genome assemblies. Bioinformatics. 2011;27:2957-63.

17. Meglecz E, Pech N, Gilles A, Dubut V, Hingamp P, Trilles A, Grenier R, Martin JF. QDD version 3.1: a user-friendly computer program for microsatellite selection and primer design revisited: experimental validation of variables determining genotyping success rate. Mol Ecol Resour. 2014;14:1302-13.

18. Thiel T, Michalek W, Varshney R, Graner A. Exploiting EST databases for the development and characterization of gene-derived SSR-markers in barley (Hordeum vulgare L.). Theor Appl Genet. 2003;106:411-22.
19. Koressaar T, Remm M. Enhancements and modifications of primer design program Primer3. Bioinformatics. 2007;23:1289-91. https://doi. org/10.1093/bioinformatics/btm091.

20. Untergasser A, Cutcutache I, Koressaar T, Ye J, Faircloth BC, Remm M, et al. Primer3-new capabilities and interfaces. Nucleic Acids Res. 2012;40:e115. https://doi.org/10.1093/nar/gks596.

21. Altschul SF, Madden TL, Schaffer AA, Zhang J, Zhang Z, Miller W, et al. Gapped BLAST and PSI-BLAST: a new generation of protein database search programs. Nucleic Acids Res. 1997;25:3389-402.

22. Kenta T, Gratten J, Haigh NS, Hinten GN, Slate J, Butlin RK, et al. Multiplex SNP-SCALE: a cost-effective medium-throughput single nucleotide polymorphism genotyping method. Mol Ecol Resour. 2008;8:1230-8. https:// doi.org/10.1111/j.1755-0998.2008.02190.x

23. Reynolds SJ, Martin GR, Wallace LL, Wearn CP, Hughes BJ. Sexing sooty terns on Ascension Island from morphometric measurements. J Zool. 2008;274:2-8. https://doi.org/10.1111/j.1469-7998.2007.00350.x.

24. Anderson CA, Pettersson FH, Clarke GM, Cardon LR, Morris AP, Zondervan $\mathrm{KT}$. Data quality control in genetic case-control association studies. Nat Protoc. 2010;5:1564-73. https://doi.org/10.1038/nprot.2010.116.

25. Kalinowski ST, Wagner AP, Taper ML. ML-Relate: a computer program for maximum likelihood estimation of relatedness and relationship. Mol Ecol Notes. 2006;6:576-9. https://doi.org/10.1111/j.1471-8286.2006.01256.x.

26. Kalinowski ST, Taper ML, Marshall TC. Revising how the computer program Cervus accommodates genotyping error increases success in paternity assignment. Mol Ecol. 2007;16:1099-106. https://doi. org/10.1111/j.1365-294X.2007.03089.x.

27. Rousset F. GENEPOP'007: a complete re-implementation of the genepop software for Windows and Linux. Mol Ecol Resour. 2008;8:103-6. https:// doi.org/10.1111/j.1471-8286.2007.01931.x.

28. Verhoeven KJF, Simonsen KL, McIntyre LM. Implementing false discovery rate control: increasing your power. Oikos. 2005;108:643-7. https://doi. org/10.1111/j.0030-1299.2005.13727.x.

29. Peakall R, Smouse PE. GENALEX 6: genetic analysis in Excel. Population genetic software for teaching and research. Mol Ecol Notes. 2006;6:28895. https://doi.org/10.1111/j.1471-8286.2005.01155.x.

30. Peakall R, Smouse PE. GenAlEx 6.5: genetic analysis in Excel. Population genetic software for teaching and research —an update. Bioinformatics. 2012;28:2537-9. https://doi.org/10.1093/bioinformatics/bts460.

31. Holleley CE, Geerts PG. Multiplex Manager 1.0: a cross-platform computer program that plans and optimizes multiplex PCR. Biotechniques. 2009;46:511-7. https://doi.org/10.2144/000113156.

32. Avise JC, Nelson WS, Bowen BW, Walker D. Phylogeography of colonially nesting seabirds, with special reference to global matrilineal patterns in the sooty tern (Sterna fuscata). Mol Ecol. 2000;9:1783-92.

\section{Submit your next manuscript to BioMed Central and we will help you at every step:}

- We accept pre-submission inquiries

- Our selector tool helps you to find the most relevant journal

- We provide round the clock customer support

- Convenient online submission

- Thorough peer review

- Inclusion in PubMed and all major indexing services

- Maximum visibility for your research

Submit your manuscript at www.biomedcentral.com/submit
(OioMed Central 